\title{
Phenotype and Cellular Response of Wheat Lines Carrying Cre Genes to Heterodera avenae Pathotype Ha91
}

Jiangkuan Cui, Huan Peng, Wenkun Huang, and Shiming Liu, State Key Laboratory for Biology of Plant Diseases and Insect Pests, Institute of Plant Protection, Chinese Academy of Agricultural Sciences, Beijing 100193, China; Duqing Wu, State Key Laboratory for Biology of Plant Diseases and Insect Pests, Institute of Plant Protection, Chinese Academy of Agricultural Sciences, Beijing 100193, China; and Centre for Plant Sciences, University of Leeds, LS2 9JT, U.K.; and Lingan Kong, Wenting He, and Deliang Peng, ${ }^{\dagger}$ State Key Laboratory for Biology of Plant Diseases and Insect Pests, Institute of Plant Protection, Chinese Academy of Agricultural Sciences, Beijing 100193, China

\begin{abstract}
The cereal cyst nematode (CCN, Heterodera avenae), a major limiting factor for wheat production worldwide, is widespread in most wheat-growing regions in China. Accordingly, screening and characterization of resistant (R) wheat sources against $H$. avenae are very important. In this study, we screened 51 wheat lines, collected from the International Wheat and Maize Improvement Center (CIMMYT), carrying various $\mathrm{Cre}$ genes (Cre 1, $\mathrm{Cre} 2$, $\mathrm{Cre} 3, \mathrm{Cre} 5, \mathrm{Cre}$ 7, $\mathrm{Cre} 8, \mathrm{CreR}$, and $\mathrm{Pt}$ ). From that screen, we identified one immune (M) cultivar (with no adult females produced) and five resistant cultivars (with fewer than five females) to $H$. avenae pathotype Ha91. The $\mathrm{Cre} 3$ gene conferred the most effective resistance against $H$. avenae pathotype Ha91 in both field and greenhouse assays. Conversely, the Crel and CreR genes conferred the poorest effective resistance. Using Pluronic F-127 gel and a staining assay, juvenile nematodes invading wheat roots were observed, and nematode development was analyzed. Compared with

$\mathrm{R}$ and $\mathrm{M}$ roots, those of the susceptible (S) wheat cultivar Wenmai19 were more attractive to $H$. avenae second-stage juveniles (J2s). We observed the retardation of nematode development in R cultivars and tiny white female cysts protruding from the R cultivar VP1620. Nematodes in M roots either disintegrated or remained J2s or third-stage juveniles (J3s) and failed to complete their life cycle. Molting was also suppressed or delayed in $\mathrm{R}$ and $\mathrm{M}$ genotypes. For both $\mathrm{S}$ and $\mathrm{R}$ cultivars, syncytia were characterized by cell wall perforations and dense cytoplasm in hypertrophied syncytium component cells. Syncytial size increased gradually with nematode development in S cultivars. Moreover, an incompatibility reaction occurred in $\mathrm{M}$ wheat roots: the syncytium was disorganized, exhibiting disintegration and condensed nuclei. These sources of genetic resistance against $\mathrm{CCN}$ can potentially be planted in severely infested fields to reduce economic loss or can be used for introgression in breeding.
\end{abstract}

The cereal cyst nematode $(\mathrm{CCN})$ Heterodera avenae is a destructive pest of cereal crops worldwide and causes significant yield losses in many countries (Cui et al. 2017; Nicol and Rivoal 2008; Smiley et al. 2011). For example, more than $50 \%$ of fields in major cerealgrowing areas in Europe are infected by this nematode, with staggering annual yield losses reaching $£ 3$ million (Nicol and Rivoal 2008). In China, more than 4 million ha in major wheat-producing regions are infected by $\mathrm{CCN}$, with losses estimated at 1.9 billion RMB per year (Peng et al. 2007, 2009). Moreover, yield losses of 16 to 55\% have occurred in China when the CCN density exceeded 10 eggs per $\mathrm{g}$ of soil (Hou et al. 2012). CCN was first reported in Hubei Province in 1989, and subsequent surveys have indicated that this species is widely distributed, being found in more than 16 provinces in China to date (Cui et al. 2015). To address the high CCN prevalence, multiple control measures, such as resistance breeding, crop rotation, nematicide application, soil plowing, and amendments, have been adopted (Nicol and Rivoal 2008; Peng et al. 2009). Peng and Cook (1996) reported that pathotypes of $H$. avenae populations in China might differ considerably from those in other regions and that there are at least three CCN pathotypes in China. Yuan et al. (2010) reported a new pathotype (Ha43) from Xushui and Xingyang, near Zhengzhou. Cui et al. (2015) classified the Daxing and Huangyuan populations as belonging to another new pathotype and named it Ha91.

However, the use of resistant $(\mathrm{R})$ cultivars is the most cost effective and promising method for CCN control (Nicol et al. 2011). Sources of resistance in barley and wild wheat relatives have been identified and verified, and genes conferring resistance to some $\mathrm{CCN}$ populations have been introgressed into various cultivars (Ogbonnaya et al. 2001). Many genes underlying resistance to CCNs, including Cre $(1-8,3 S$,

${ }^{\dagger}$ Corresponding author. E-mail: dlpeng@ippcaas.cn

Accepted for publication 30 June 2017.

(c) 2017 The American Phytopathological Society
$R$ ) genes, $\mathrm{Ha}(1-4)$ genes, the $R 1$ gene, and many other dominant or minor genes, have been identified using traditional mapping-based cloning strategies. The $\mathrm{Cre} 1$ and $\mathrm{Cre} 8$ genes were identified directly in Triticum aestivum, AUS 10894/AUS 4930, and Festiguay (de Majnik et al. 2003; Safari et al. 2005). In contrast, the $\mathrm{Cre} 2, \mathrm{Cre} 5$, and Cre6 genes were derived from Aegilops ventricosa (Jahier et al. 2001; Ogbonnaya et al. 2001; Rivoal et al. 2001) and Cre3 and Cre4 from A. tauschii (de Majnik et al. 2003; Rivoal et al. 2001). In addition, the Cre3S and $\mathrm{Cre} 7$ genes originated from A. peregrina and A. triuncialis, respectively (Jahier et al. 1998; Romero et al. 1998). CreR was identified in Secale cereale (Taylor et al. 1998), and $\mathrm{CreX}$ and $\mathrm{CreY}$ were derived from A. variabilis (Barloy et al. 2007). Furthermore, seven resistance genes, Rhal, Rhal+, Rha2, Rha2+, Rha3+, Rha4, and RhaE, were derived from barley (Barr et al. 1998; Seah et al. 2000; Smiley et al. 2011). The resistance gene $R I$ and three dominant genes $(A, B$, and $C)$, as well as many minor genes, have also been identified in wild oat (Avena sterilis) (Clamot and Rivoal 1984; Smiley et al. 2011). Further, the Pt gene identified from the bread wheat line GS50a, showing good resistance to Pratylenchus thornei, has been used in wheat breeding programs (Thompson et al. 1999; Zwart et al. 2004).

Pluronic F-127 gel has been used as a medium for studying nematodes because this transparent gel allows nematodes to travel freely, allowing three-dimensional assays (Wang et al. 2009). For example, Sasaki-Crawley et al. (2012) successfully applied Pluronic F-127 gel studies to compare Globodera pallida development in Solanum tuberosum and S. sisymbriifolium. The attraction of $H$. filipjevi or $H$. avenae juveniles toward root tips of wheat strains differing in resistance to $\mathrm{CCN}$ has also been investigated using Pluronic F-127 gel as a medium (Cui et al. 2012; Hu et al. 2015). Sedentary endoparasitic phytonematodes have acquired the ability to generate feeding sites in host cells to facilitate nutrient uptake (Mitchum et al. 2013). Dissolution of localized cell walls and protoplast fusion cause the syncytium to progressively enlarge until it ultimately incorporates up to 200 neighboring cells (Lilley et al. 2005). Nonetheless, there are large differences in syncytial composition between CCN R and susceptible (S) wheat cultivars (Aditya et al. 2015). Similarly, roots of both $S$ and $\mathrm{R}$ cultivars are easily invaded by $H$. avenae $\mathrm{J} 2 \mathrm{~s}$, although reduced 
numbers of white female cysts and decreased $H$. avenae egg density in soil are observed with R cultivars (Marshall and Smiley 2016).

The objectives of this study were 1) to screen international sources of R wheat carrying Cre genes that could be transferred to locally adapted cultivars via introgression and deployed to control CCNs in China; 2) to use Pluronic F-127 to study the phenotype in response to $\mathrm{CCN}$ infection of wheat varieties carrying Cre genes; and 3 ) to assess host cellular responses of different $\mathrm{R}$ wheat varieties carrying Cre genes to $H$. avenae pathotype Ha91.

\section{Materials and Methods}

Nematode collection. CCNs in soil were collected from infested wheat fields in Daxing, Beijing, China, at the end of the wheatgrowing season. Cysts were extracted from the soil using Cobb's sieving gravity method (Persmark et al. 1992). As reported by Cui et al. (2015), the collected nematodes were identified as H. avenae, and the pathotype was identified as $\mathrm{Ha} 91$.

Resistance tests. Field resistance test. A CCN-infested field in the wheat-producing area of Daxing, Beijing, China, was used for field resistance tests during the 2012-13 season. According to previous experiments, the average density was 25 to 30 cysts per $200 \mathrm{~g}$ of soil (Hao et al. 2014). Fifty wheat lines collected from the CIMMYT (35 resistant wheat sources and 15 sources carrying different $C r e$ genes [Cre1, Cre2, Cre3, Cre5, Cre7, Cre8, CreR, and Pt]) and one local control (Wenmai19) were tested. Twenty seeds were manually planted with uniform spacing in a $1-\mathrm{m} \times 2-\mathrm{m}$ plot with four rows, and three replicates were included as randomized blocks. During Feekes growth stage 10.5.3 (Miller 1992), five wheat plants per plot were randomly selected, and newly formed white female cysts were counted (Marshall and Smiley 2016). The $S$ wheat cultivar Wenmai 19 was used as a local control. The resistance of cultivars was classified based on the number of cysts per root system: $\mathrm{M}=$ immune ( 0 females); $\mathrm{R}$ ( 0.1 to $5.0 \mathrm{fe}-$ males); MR = moderately $\mathrm{R}$ (5.1 to 10.0 females); $\mathrm{MS}=$ moderately $\mathrm{S}$ (10.1 to 15.0 females); S (15.1 to 25.0 females); and HS = highly $\mathrm{S}$ (>25.0 females) (Nicol et al. 2009).

Pot resistance test. To confirm resistance, greenhouse tests are generally more reliable than field tests because the field environment is variable (Yuan et al. 2011). Thus, we performed two greenhouse tests in 2013 and 2014. Seeds of each cultivar were germinated in Petri dishes and then transplanted into polyvinyl chloride tubes ( $3 \mathrm{~cm}$ in diameter, $30 \mathrm{~cm}$ in length) with $200 \mathrm{~cm}^{3}$ of a sterile soil mixture (loamy soil-compost-sand at 3:2:5). H. avenae cysts were hatched at 14 to $16^{\circ} \mathrm{C}$; simultaneously, freshly hatched $\mathrm{J} 2 \mathrm{~s}$ were used to infect wheat roots (Cui et al. 2015). A total of $300 \mathrm{~J} 2 \mathrm{~s}$ were inoculated into each tube immediately after the seeds were planted, after which inoculations with 300 or $200 \mathrm{~J} 2 \mathrm{~s}$ were performed at 3-day intervals, resulting in a final inoculum density of $800 \mathrm{~J} 2 \mathrm{~s}$ per tube. Ten replicates were performed for each cultivar. The plants were successively grown in a greenhouse for 1 week at $14 / 18^{\circ} \mathrm{C}, 1$ week at 16 / $20^{\circ} \mathrm{C}, 3$ weeks at $18 / 25^{\circ} \mathrm{C}$, and 2 weeks at $22 / 30^{\circ} \mathrm{C}$, with an 8 -h dark/16-h light cycle under normal plant growth conditions, including irrigation, fertilization, and control of diseases and insects. Seven weeks later, after the last inoculation, plants and soil samples were washed over a $250-\mu \mathrm{m}$ sieve using a gentle stream of tap water. White females that were attached to roots and in the surrounding soil were collected and counted under a stereoscopic microscope, and the mean number of white females per plant was calculated. The resistance of each cultivar was classified as described above.

Attraction ability test. According to the results of resistance classification described above, the S cultivar Wenmai19, the R cultivar VP1620, and the M cultivar CROC-1/AE.SQUARROSA (224)// OPATA*B (Croc B) were selected for attraction tests, as described by Wang et al. (2009). To produce 23\% (w/v) Pluronic F-127 gels (Sigma Aldrich, St. Louis, MO), 23 g of Pluronic F-127 powder was first added to sterile water at 2 to $4^{\circ} \mathrm{C}$ and dissolved by stirring overnight in a final volume of $100 \mathrm{ml}$. The dissolved gel was then stored at $4{ }^{\circ} \mathrm{C}$ prior to use. Next, $1 \mathrm{ml}$ of gel containing approximately $800 \mathrm{~J} 2 \mathrm{~s}$ and one sterile 3 -day-old wheat root tip ( $1 \mathrm{~cm}$ in length) were added to wells of 12-well tissue culture plates. The culture plates were maintained in a plant growth chamber (Jiangnan Instrument
Co., Ltd, Ningbo, China) at $14 \pm 1^{\circ} \mathrm{C}$. The attracted J2s surrounding the wheat tips within $0.3 \mathrm{~cm}$ were counted at $2,4,6,12$, and $24 \mathrm{~h}$ after the experiment began, and photographs were obtained using a Leica dissecting microscope (Leica M165C, Wetzlar, Germany). Five replicates were performed for every cultivar, and each assay was performed three times.

Juvenile development analysis. Analysis of differences in juvenile nematode invasion, development, and reproduction can provide information about active resistance mechanisms (Pariyar et al. 2016). To identify the resistance mechanisms involved in different wheatnematode interactions, we tested cultivars carrying different resistance genes. A pot experiment was conducted by counting the numbers of $\mathrm{J} 2 \mathrm{~s}, \mathrm{~J} 3 \mathrm{~s}$, and fourth-stage juveniles (J4s) in the roots of the abovementioned $\mathrm{S}, \mathrm{R}$, and $\mathrm{M}$ wheat cultivars at 5,15 , and 25 days after inoculation (DAI). Five wheat plants were randomly selected, and the roots were then carefully washed and stained with acid fuchsin, as described by Bybd et al. (1983). Juvenile CCNs at different developmental stages were examined for morphology and counted using a Leica dissecting microscope (Leica M165C, Wetzlar, Germany). Five replicates were performed for each cultivar, and each assay was performed three times.

Cellular response analysis. Andres et al. (2001) reported that infection of $\mathrm{R}$ wheat lines with $H$. avenae results in a hypersensitive reaction with deterioration of syncytial cells, whereas the syncytia of $S$ wheat cultivars continue to enlarge. To study the underlying resistance mechanism, the roots of infected S, R, and M plants were harvested at 5, 10, 15, and $25 \mathrm{DAI}$ and then stained using the acid fuchsin method. The samples were rinsed in distilled water twice for $3 \mathrm{~min}$ each, and the roots were subsequently incubated for $2 \mathrm{~h}$ in $1 \%$ acid fuchsin solution at $37^{\circ} \mathrm{C}$ and rinsed in distilled water. Root samples $1 \mathrm{~cm}$ in length were collected from each test plant, immersed overnight in $3 \%$ glutaraldehyde, and dehydrated by passage through a graded ethanol series (10 to 100\%). The samples were then infiltrated and embedded in paraffin at $60^{\circ} \mathrm{C}$, after which they were sectioned using a JB-4 microtome. The sections were stained for $5 \mathrm{~min}$ with $1 \%$ toluidine blue in $1 \%$ borax solution (TAAB) at $40^{\circ} \mathrm{C}$ as described by Kong et al. (2016). The syncytial sizes of Wenmai19, VP1620, and Croc B were measured at 5, 15, and 25 DAI as previously described (Siddique et al. 2012). For each wheat plant, 10 syncytia were randomly selected and examined; the structures were outlined, and their areas were calculated by using software with a Leica M165C microscope (Kong et al. 2016).

Statistical analysis. Statistical analysis was performed on the number of white female cysts identified in the greenhouse pot trials and field tests, the number of attracted J2s in Pluronic F-127, and the numbers of juveniles of different developmental stages per root as well as on the growth indices of syncytial areas. Analysis of variance (ANOVA) was performed individually for each experiment. Significant differences $(P \leq 0.05)$ among treatments were determined by using the least significant difference (LSD) test using SPSS 12.0 software (SPSS Inc.).

\section{Results}

Resistance test. To identify valuable genetic resources for wheat breeding programs, we evaluated 51 wheat cultivars carrying Cre genes, all obtained from CIMMYT. In the field test (2012), 14 cultivars were found to be HS, $16 \mathrm{~S}, 12 \mathrm{MS}$, four MR, and four R; Croc B was M (Table 1). In pot tests (2013 and 2014), the results from 2013 were similar to those from 2014. In 2013, 35 cultivars were HS, seven S, three MS, and three MR; VP1620 (Cre3) and Croc A were R, and Croc B was M (Table 1). In 2014, 37 cultivars were HS, seven S, and four MR; VP1620 (Cre3) and Croc A were R, and Croc B was M; no cultivars were MS (Table 1). Based on the three years of screening results, Croc B was consistently $\mathrm{M}$ to $H$. avenae pathotype $\mathrm{Ha} 91$ in both field and greenhouse tests. Wheat cultivar VP1620, which carried the $\mathrm{Cre} 3$ resistance gene, was highly effective in suppressing $H$. avenae reproduction. Lines derived from the same variety exhibited an identical or similar resistance level, and Croc A was also $\mathrm{R}$ to this population; however, the resistance gene has yet to be identified in Croc A and Croc B (Table 2). In the field trial, prevention of 
Table 1. Evaluation of 51 cultivars from CIMMYT carrying Cre genes in the presence of H. avenae pathotype Ha91 in field and greenhouse trials from 2012 to 2014

\begin{tabular}{|c|c|c|c|c|c|c|c|}
\hline \multirow[b]{2}{*}{ Line name ${ }^{u}$} & \multirow[b]{2}{*}{ Gene $^{\text {v }}$} & \multicolumn{2}{|c|}{$2012^{w}$} & \multicolumn{2}{|c|}{$2013^{x}$} & \multicolumn{2}{|c|}{$2014^{x}$} \\
\hline & & Mean \pm SDy & Reaction $^{z}$ & Mean \pm SD $^{y}$ & Reaction $^{\mathbf{z}}$ & Mean \pm SD $^{y}$ & Reaction $^{2}$ \\
\hline DAGDAS CHECK & & $51.6 \pm 6.77$ & HS & $68.1 \pm 3.75$ & HS & $63.6 \pm 3.72$ & HS \\
\hline $\begin{array}{l}\text { MAYOOR//TKSN1081/AE.SQUARROSA } \\
(222)\end{array}$ & & $47.0 \pm 8.39$ & HS & $38.7 \pm 4.13$ & HS & $43.5 \pm 3.03$ & HS \\
\hline ES84-24/DYNASTY & & $44.0 \pm 5.83$ & HS & $40.0 \pm 4.24$ & HS & $66.5 \pm 3.63$ & HS \\
\hline Silverstar & Crel & $38.2 \pm 2.59$ & HS & $45.9 \pm 4.95$ & HS & $44.1 \pm 3.48$ & HS \\
\hline BILINMIYEN96.7 & & $33.4 \pm 6.22$ & HS & $44.5 \pm 3.27$ & HS & $51.0 \pm 3.74$ & HS \\
\hline LOCAL CHECK & & $33.6 \pm 5.22$ & HS & $40.6 \pm 4.14$ & HS & $58.8 \pm 4.23$ & HS \\
\hline LOV41//LI7/LE2062 & & $33.2 \pm 3.83$ & HS & $62.0 \pm 3.43$ & HS & $72.7 \pm 4.42$ & HS \\
\hline GS50A & $P t$ & $31.8 \pm 5.40$ & HS & $53.6 \pm 4.48$ & HS & $38.9 \pm 2.51$ & HS \\
\hline $2-49$ & & $29.6 \pm 3.91$ & HS & $39.4 \pm 4.09$ & HS & $34.6 \pm 3.84$ & HS \\
\hline CPI133859 & & $28.2 \pm 4.43$ & HS & $35.8 \pm 3.99$ & HS & $42.0 \pm 2.98$ & HS \\
\hline Chara & Crel & $28.8 \pm 3.56$ & HS & $16.2 \pm 2.69$ & $S$ & $17.7 \pm 2.83$ & $S$ \\
\hline AUS 10894 & Crel & $28.2 \pm 3.89$ & HS & $36.1 \pm 3.95$ & HS & $35.1 \pm 4.23$ & HS \\
\hline SUNCO & & $25.2 \pm 1.92$ & HS & $36.4 \pm 3.63$ & HS & $37.1 \pm 2.60$ & HS \\
\hline CPI133872 & & $25.1 \pm 3.80$ & $\mathrm{~S}$ & $54.8 \pm 7.19$ & HS & $57.4 \pm 5.58$ & HS \\
\hline SABUF/7/ALTAR84 & & $23.2 \pm 4.55$ & $S$ & $59.4 \pm 5.21$ & HS & $61.3 \pm 3.62$ & HS \\
\hline VP5053 & Cres & $23.2 \pm 2.48$ & $\mathrm{~S}$ & $63.5 \pm 4.14$ & HS & $33.2 \pm 3.88$ & HS \\
\hline KRC66/SERI/4/YMH/TOB//MCD/3/LIRA & & $22.4 \pm 3.51$ & $S$ & $35.5 \pm 5.19$ & HS & $43.2 \pm 1.93$ & HS \\
\hline Potch92 & & $22.0 \pm 4.52$ & $S$ & $34.6 \pm 3.72$ & HS & $67.5 \pm 3.02$ & HS \\
\hline $\begin{array}{l}\text { SABUF/3/BCN//CETA/AE.SQUARROSA } \\
\text { (895) }\end{array}$ & & $21.0 \pm 3.08$ & $S$ & $46.5 \pm 6.34$ & HS & $82.3 \pm 3.77$ & HS \\
\hline ALTAY 2000 & & $20.8 \pm 4.15$ & $\mathrm{~S}$ & $37.5 \pm 5.25$ & HS & $37.1 \pm 2.92$ & HS \\
\hline ID-2150 & Cre2 2 & $20.2 \pm 3.70$ & $\mathrm{~S}$ & $39.3 \pm 4.59$ & HS & $64.7 \pm 2.75$ & HS \\
\hline GS50A T41.1 & $P t ?$ & $19.2 \pm 3.89$ & $\mathrm{~S}$ & $41.8 \pm 6.14$ & HS & $16.5 \pm 2.17$ & S \\
\hline AUSGS50AT34/SUNCO//CUNNINGHAM-98 & & $19.0 \pm 2.74$ & $\mathrm{~S}$ & $39.2 \pm 4.64$ & HS & $36.3 \pm 2.83$ & HS \\
\hline GATCHER & & $18.2 \pm 3.27$ & $\mathrm{~S}$ & $38.5 \pm 3.17$ & HS & $25.8 \pm 2.85$ & HS \\
\hline VL411R & & $16.4 \pm 2.88$ & $\mathrm{~S}$ & $36.9 \pm 3.93$ & HS & $45.6 \pm 2.67$ & HS \\
\hline $6 \mathrm{R}(6 \mathrm{D})$ & CreR & $16.2 \pm 2.38$ & $\mathrm{~S}$ & $36.9 \pm 3.73$ & HS & $37.6 \pm 3.53$ & HS \\
\hline SUNCO/2*PASTOR & & $15.4 \pm 1.67$ & $\mathrm{~S}$ & $36.7 \pm 2.75$ & HS & $36.3 \pm 3.19$ & HS \\
\hline F130L1.12/ATTILA & & $15.2 \pm 1.92$ & $\mathrm{~S}$ & $29.2 \pm 3.71$ & HS & $52.8 \pm 4.26$ & HS \\
\hline BURBOT-6 & & $15.4 \pm 1.87$ & $\mathrm{~S}$ & $27.2 \pm 4.31$ & HS & $30.6 \pm 2.98$ & HS \\
\hline SONMEZ & & $14.4 \pm 1.52$ & MS & $59.5 \pm 5.85$ & HS & $33.8 \pm 3.96$ & HS \\
\hline AUS4930.7 & Cre1? & $14.0 \pm 3.16$ & MS & $16.5 \pm 3.24$ & S & $20.7 \pm 3.06$ & $\mathrm{~S}$ \\
\hline T-2003 & $\mathrm{Cre} 7$ & $13.8 \pm 1.78$ & MS & $23.4 \pm 3.37$ & S & $24.2 \pm 1.87$ & $S$ \\
\hline BATAVIA & & $13.8 \pm 1.64$ & MS & $31.3 \pm 3.53$ & HS & $37.1 \pm 3.66$ & HS \\
\hline ZANDER-44 & & $12.0 \pm 1.58$ & MS & $22.3 \pm 3.40$ & $S$ & $18.2 \pm 2.65$ & $S$ \\
\hline WARIGAL & & $11.2 \pm 0.19$ & MS & $27.8 \pm 1.87$ & HS & $29.2 \pm 2.61$ & HS \\
\hline GOLDMARK & & $11.0 \pm 2.73$ & MS & $20.5 \pm 2.37$ & $\mathrm{~S}$ & $28.6 \pm 2.50$ & HS \\
\hline ES84.24/GRK & & $10.8 \pm 2.05$ & MS & $24.4 \pm 2.67$ & $S$ & $27.4 \pm 3.09$ & HS \\
\hline AUS4930.7/2*PASTOR & Cre1? & $10.8 \pm 1.92$ & MS & $18.8 \pm 3.48$ & S & $36.3 \pm 2.83$ & HS \\
\hline SERI & & $10.6 \pm 2.30$ & MS & $25.9 \pm 2.51$ & HS & $53.5 \pm 3.34$ & HS \\
\hline $\begin{array}{l}\text { ALTAR 84/AEGILOPS SQUARROSA } \\
\text { (TAUS)//OPATA }\end{array}$ & & $10.2 \pm 1.92$ & MS & $42.2 \pm 2.53$ & HS & $40.9 \pm 2.76$ & HS \\
\hline Frame & Cres & $10.2 \pm 3.27$ & MS & $13.5 \pm 3.87$ & MS & $8.4 \pm 0.97$ & MR \\
\hline IWA 8604765(PI 628144) & & $8.2 \pm 1.48$ & MR & $11.1 \pm 0.88$ & MS & $23.9 \pm 2.77$ & S \\
\hline IWA 8608077 (PI 621458) & & $8.0 \pm 2.24$ & MR & $14.7 \pm 0.95$ & MS & $18.2 \pm 2.86$ & S \\
\hline MILAN & Cre5? & $7.4 \pm 1.14$ & MR & $8.2 \pm 3.96$ & MR & $6.6 \pm 1.71$ & MR \\
\hline KATEA-1 & & $6.2 \pm 1.92$ & MR & $5.5 \pm 2.67$ & MR & $9.1 \pm 1.52$ & MR \\
\hline VP1620 & Cre3 & $4.6 \pm 1.52$ & $\mathrm{R}$ & $4.8 \pm 1.23$ & $\mathrm{R}$ & $4.1 \pm 1.37$ & $\mathrm{R}$ \\
\hline VENTURA(SUN376G) & & $3.6 \pm 0.89$ & $\mathrm{R}$ & $5.3 \pm 1.63$ & MR & $7.0 \pm 1.49$ & MR \\
\hline AUS4930 6.5/GS50A & Pt? & $3.4 \pm 1.14$ & $\mathrm{R}$ & $28.2 \pm 2.04$ & HS & $33.2 \pm 2.44$ & HS \\
\hline $\begin{array}{l}\text { CROC1/AE.SQUARROSA } \\
(224) / / \text { OPATA*A }\end{array}$ & & $0.2 \pm 0.84$ & $\mathrm{R}$ & $1.6 \pm 1.43$ & $\mathrm{R}$ & $0.9 \pm 0.87$ & $\mathrm{R}$ \\
\hline $\begin{array}{l}\text { CROC_1/AE.SQUARROSA } \\
(224) / / \text { OPATA*B }\end{array}$ & & 0 & M & 0 & M & 0 & M \\
\hline Wenmai19 & & $45.0 \pm 7.52$ & HS & $62.8 \pm 1.87$ & HS & $66.5 \pm 3.03$ & HS \\
\hline
\end{tabular}


H. avenae reproduction was observed for MILAN wheat cultivars carrying the Cre5 gene. AUS4930 6.5/GS50A, which carried the Pt gene, as well as IWA 8604765 (PI 628144), IWA 8608077 (PI 621458), KATEA-1, and VENTURA (SUN376G), were MR (Table 2). The resistance reactions in the present study were almost in accordance with the report by $\mathrm{Li}$ et al. (2013) (Table 3). Wheat cultivars carrying the $\mathrm{Crel}$ and $\mathrm{CreR}$ genes exhibited the lowest effective resistance to $H$. avenae pathotype Ha91, findings that were obviously different from the results of Smiley (2014), Smiley et al. (2011), Yuan et al. (2011), Nicol and Rivoal (2008), and Nicol et al. (2009) (Table 3). Cre7 and Cre8 resistance genes were also ineffective at suppressing $H$. avenae reproduction, with reactions comparable to those reported by Li et al. (2013), Yuan et al. (2011), Nicol and Rivoal (2008), and Nicol et al. (2009), but not by Smiley (2014) or Smiley et al. (2011) (Table 3).

Attraction test. In the present study, $H$. avenae J2s were quickly attracted to wheat roots in Pluronic F-127 gel, and those that traveled within $3 \mathrm{~mm}$ of the roots were counted. We found that most J2s directly and rapidly migrated toward roots, whereas others traveled in a more curved fashion, with their head and tail relatively close together. The nematodes that traveled in a curved fashion moved slowly forward or backward in circles and displayed almost no change in position (Fig. 1). In the Pluronic F-127 gel, H. avenae $\mathrm{J} 2 \mathrm{~s}$ traveled toward wheat roots within the first $2 \mathrm{~h}$ after initiation of the attraction test. The number of $\mathrm{J} 2 \mathrm{~s}$ in contact with roots increased over time. By 4, 6, 12, and $24 \mathrm{~h}$ after initiation, the numbers of J2s surrounding the root tip had increased to 63.3, 99.3, 137.7, and 143.7 for Wenmai19; 48.0, 84.3, 106.7, and 114.0 for VP1620; and 39.7, 51.0, 59.7, and 60.3 for Croc B, respectively (Fig. 2). The roots of the $\mathrm{S}$ wheat cultivar Wenmai19 were more attractive to $H$. avenae $\mathrm{J} 2 \mathrm{~s}$ than were $\mathrm{R}$ and $\mathrm{M}$ roots. Although the roots became dehydrated after approximately $24 \mathrm{~h}$, and the ability of the wheat roots to attract decreased over time, the number of $\mathrm{J} 2 \mathrm{~s}$ increased slowly, peaking at $24 \mathrm{~h}$. We also counted the number of $\mathrm{J} 2 \mathrm{~s} 48 \mathrm{~h}$ after initiation, but no changes were observed relative to $24 \mathrm{~h}$. Overall, 143.7, 114.0, and $60.3 \mathrm{~J} 2 \mathrm{~s}$ were observed surrounding Wenmai19, VP1620 (Cre 3), and Croc B roots, respectively (Fig. 2).

Juvenile development analysis. We assessed the effects of different cultivars on juvenile CCNs by counting the numbers of $\mathrm{J} 2 \mathrm{~s}, \mathrm{~J} 3 \mathrm{~s}$, and $\mathrm{J} 4 \mathrm{~s}$ in wheat roots. The roots of $\mathrm{S}, \mathrm{R}$, and $\mathrm{M}$ cultivars were stained at 5, 15, and 25 DAI. At 5 DAI, the numbers of established nematodes in $\mathrm{R}$ and $\mathrm{M}$ roots were significantly lower than that in $\mathrm{S}$ roots, with an average of $248 \mathrm{~J} 2 \mathrm{~s}$ being observed in cv. Wenmai19 roots but only an average of 56 in VP1620 roots and 31 in Croc B roots. The number of penetrated $\mathrm{CCN}$ juveniles decreased gradually over time (Table 2). At $15 \mathrm{DAI}$, the total numbers of $\mathrm{CCN}$ juveniles in the roots were 135, 20, and 10 in Wenmai19, VP1620, and Croc B, respectively. At $15 \mathrm{DAI}$, the proportion of $\mathrm{CCN}$ juveniles that had become J3s was more than $90 \%$ in Wenmai19, whereas it was decreased to $71 \%$ in VP1620 and only $26 \%$ in Croc B. In Wenmai19

Table 2. Numbers of different $H$. avenae developmental stages observed within susceptible, resistant, and immune wheat roots.

\begin{tabular}{llccc}
\hline & & \multicolumn{2}{c}{ No. of different stages of juveniles } \\
\cline { 3 - 5 } Time $^{\mathbf{z}}$ & Cultivars $^{\mathbf{y}}$ & $\mathbf{J 2 s}$ & $\mathbf{J 3 s}$ & \multicolumn{1}{c}{ J4s } \\
\hline 5 DAI & Wenmai19 & $248.0 \pm 16.09 \mathrm{a}$ & 0 & 0 \\
& VP1620 & $56.0 \pm 9.17 \mathrm{~b}$ & 0 & 0 \\
& Croc B & $30.7 \pm 4.16 \mathrm{c}$ & 0 & 0 \\
$15 \mathrm{DAI}$ & Wenmai19 & $12.3 \pm 1.53 \mathrm{a}$ & $122.3 \pm 5.13 \mathrm{a}$ & 0 \\
& VP1620 & $5.7 \pm 1.15 \mathrm{~b}$ & $14.0 \pm 3.46 \mathrm{~b}$ & 0 \\
& Croc B & $7.6 \pm 1.53 \mathrm{~b}$ & $2.7 \pm 0.58 \mathrm{c}$ & 0 \\
25 DAI & Wenmai19 & 0 & $4.7 \pm 1.15 \mathrm{a}$ & $53.3 \pm 4.51 \mathrm{a}$ \\
& VP1620 & $1.3 \pm 1.52 \mathrm{a}$ & $4.3 \pm 2.08 \mathrm{a}$ & $3.7 \pm 3.06 \mathrm{~b}$ \\
& Croc B & $2.3 \pm 0.57 \mathrm{a}$ & $1.4 \pm 0.57 \mathrm{~b}$ & 0 \\
\hline
\end{tabular}

x DAI, days after inoculation.

y Wenmai19, susceptible wheat host; VP1620, resistant wheat host; Croc B, immune wheat host.

${ }^{\mathrm{z}}$ Mean \pm standard deviation of the mean from five wheat root replicates. Different letters denote significant differences $(P \leq 0.05)$. J2, second-stage juvenile; J3, third-stage juvenile; J4, fourth-stage juvenile. roots at $25 \mathrm{DAI}$, the overwhelming majority of the penetrated $\mathrm{J} 2 \mathrm{~s}$ were able to develop into $\mathrm{J} 4 \mathrm{~s}$. In contrast, we found that nematodes did not develop into J4s in the M cultivar Croc B. CCN juveniles in VP1620 were developmentally retarded, with only $40 \%$ developing into J4s (Fig. 3). At 35 DAI, white female cysts were observed protruding from the roots of the $\mathrm{S}$ cultivar but not from those of the $\mathrm{M}$ and $\mathrm{R}$ cultivars. The nematodes in Croc $\mathrm{B}$ roots either disintegrated or remained $\mathrm{J} 2 \mathrm{~s}$ or $\mathrm{J} 3 \mathrm{~s}$ and failed to complete their life cycle. However, in VP1620, tiny white female cysts protruded nearly 10 days later than in the $\mathrm{S}$ cultivar.

Cellular response analysis. How nematodes alter root cell development to produce and maintain syncytia is a question of great interest. In root slices of the $\mathrm{S}$ cultivar, most nematodes had penetrated within $48 \mathrm{~h}$ and then migrated to the stelar regions, where the feeding sites (syncytia) had been initiated. However, syncytia were initiated later in $\mathrm{M}$ and $\mathrm{R}$ roots; in M roots, syncytia were initiated at 5 DAI. We selected four time points $(5,10,15$, and $25 \mathrm{DAI})$ for analysis in accordance with CCN development into J2s, J3s, and J4s (Fig. 4). At $5 \mathrm{DAI}$, necrosis had initiated adjacent to the nematode lip region in $\mathrm{M}$ and R roots (Fig. 4A, E). At 10 DAI, extreme nuclear hypertrophy was always observed in the syncytium of the $S$ host. In cv. Wenmai19, a major portion of the syncytium stretched over the vascular tissue (Fig. 4J). In contrast, syncytia in VP1620 formed inside the vascular tissue, starting at the endodermis and enclosing xylem elements (Fig. $4 \mathrm{~F}$ ), and in Croc B, syncytia were located in cortical cells, adjacent to the endodermis, and outside of the central area of the vascular bundle (Fig. 4B). By 15 DAI, a major change occurred in the appearance of the syncytia in the $\mathrm{S}$ cultivar: the syncytia were highly active, with hypertrophied nuclei and fewer large vacuoles (Fig. 4K). In contrast, the syncytia of the $\mathrm{R}$ cultivar were still dominated mainly by large vacuoles with weakly stained cytoplasm, indicating low activity, and the vascular elements were forced into irregular arrangements to avoid lateral roots and large syncytia (Fig. 4J). An incompatibility reaction occurred in roots of the $\mathrm{M}$ cultivar: the syncytium was disorganized, exhibiting disintegration and appearing to be inactive and nonfunctional (Fig. 4C). Continuous syncytial development was observed over a period of $25 \mathrm{DAI}$. The syncytia of the $\mathrm{S}$ cultivar exhibited dense cytoplasm with numerous subcellular organelles (Fig. 4L). In contrast, the cytoplasm in the syncytia of the R cultivar was reduced to a thin layer around the cell walls and wall fragments. After nuclear degeneration, the cytoplasm also appeared to undergo degradation (Fig. 4H). At $25 \mathrm{DAI}$, the syncytia of the M cultivar exhibited complete tonoplast breakdown and may have been completely nonfunctional. No structurally recognizable nuclei were observed in these syncytia, indicating that the nuclei had likely degenerated (Fig. 4D). Over the same period, the syncytial cells of Wenmai 19 were considerably larger than those of the R and M cultivars (Fig. 5).

\section{Discussion}

The sources of resistance to $H$. avenae identified to date have predominantly originated from wild relatives of wheat in the Aegilops genus and have already been transferred to hexaploid wheat backgrounds for breeding purposes via introgression (Nicol et al. 2011). Assessment of the relative resistance of genotypes includes growing plants in soil at sites of high infestation or in naturally infested soil transported to controlled environmental conditions (Eastwood et al. 1991). A comparison of tests conducted in the current study under field and greenhouse conditions revealed that 11 wheat cultivars showed higher susceptibility in the greenhouse than in the field, whereas none of the cultivars except for cv. Chara showed higher susceptibility in the field than in the greenhouse (Table 2). VP1620 (Cre3) exhibited significantly greater resistance than was associated with any of the other $\mathrm{Cre}$ genes in the tested group (Table 2). Cre3 has also been shown to be moderately effective against $H$. avenae populations in Hebei, China, but not against $H$. avenae and $H$. filipjevi populations in Henan (Nicol et al. 2009) (Table 3). Safari et al. (2005) reported that in Australia, the most marked reduction in the number of female cysts was produced by $\mathrm{Cr} 3$, followed by $\mathrm{Cre} \mathrm{I}$ and $\mathrm{Cre}$. In addition, $\mathrm{Cre} 3$ and $\mathrm{Cr} e 6$ provide better resistance than $\mathrm{Crel}$ against pathotype $\mathrm{Ha} 13$ but are susceptible to pathotypes Ha11 and Ha12 (Ogbonnaya et al. 2001). 
A previous study clearly demonstrated that the presence of the resistance genes $\mathrm{Cre} 2$, $\mathrm{Cre} 3, \mathrm{Cr} 5$, $\mathrm{Cre}$ 7, or $\mathrm{Cre} 8$ in wheat does not adequately suppress $H$. avenae reproduction in soil from the U.S. Pacific Northwest, whereas wheat cultivars carrying Crel are highly effective at suppressing $H$. avenae reproduction (Smiley 2014;
Smiley et al. 2011) (Table 3). Nicol and Rivoal (2008) indicated that the effects of certain Cre genes depend on both the CCN species and pathotype. Cre 2 confers a high level of resistance to populations of $H$. avenae pathotypes $\mathrm{Ha} 71$ and $\mathrm{Ha} 11$ as well as Ha12 and Ha41 but is ineffective against $\mathrm{HgI}$ to $\mathrm{HgIII}$ and $\mathrm{Ha} 13$ (Delibes et al.

Table 3. Resistance reactions of wheat from CIMMYT carrying Cre genes to CCN species and populations according to the present study and previous reports ${ }^{\mathrm{w}}$

\begin{tabular}{|c|c|c|c|c|c|c|c|c|}
\hline \multirow[b]{2}{*}{ Line name } & \multirow[b]{2}{*}{ Gene } & \multicolumn{3}{|c|}{ Present study ${ }^{x}$} & \multirow{2}{*}{$\frac{\text { Li et al.y }}{2013}$} & \multirow{2}{*}{$\frac{\text { Smiley et al.y }}{2011 \text { and } 2014}$} & \multirow{2}{*}{$\frac{\text { Yuan et al. }}{2011}$} & \multirow{2}{*}{$\frac{\text { Nicol et al. }{ }^{\mathrm{z}}}{2008 \text { and } 2009}$} \\
\hline & & 2012 & 2013 & 2014 & & & & \\
\hline DAGDAS CHECK & & HS & HS & HS & HS & $*$ & HS & $\mathrm{N}$ \\
\hline $\begin{array}{l}\text { MAYOOR//TKSN1081/AE.SQUARROSA } \\
(222)\end{array}$ & & HS & HS & HS & S & $*$ & HS & $\mathrm{N}$ \\
\hline ES84-24/DYNASTY & & HS & HS & HS & HS & $*$ & HS & $\mathrm{N}$ \\
\hline Silverstar & Crel & HS & HS & HS & HS & M & HS & MR \\
\hline BILINMIYEN96.7 & & HS & HS & HS & $*$ & $*$ & $*$ & $*$ \\
\hline LOCAL CHECK & & HS & HS & HS & $*$ & $*$ & $*$ & $*$ \\
\hline LOV41//LI7/LE2062 & & HS & HS & HS & HS & $*$ & $*$ & $\mathrm{~N}$ \\
\hline GS50A & $P t$ & HS & HS & HS & $\mathrm{S}$ & $*$ & HS & $\mathrm{N}$ \\
\hline $2-49$ & & HS & HS & HS & MS & $*$ & HS & $\mathrm{N}$ \\
\hline CPI133859 & & HS & HS & HS & $*$ & $\mathrm{~S}$ & $*$ & MS \\
\hline Chara & Crel & HS & $\mathrm{S}$ & $\mathrm{S}$ & $\mathrm{S}$ & $\mathrm{R}$ & HS & MR \\
\hline AUS10894 & Crel & HS & HS & HS & $*$ & M & $*$ & $*$ \\
\hline SUNCO & & HS & HS & HS & $\mathrm{S}$ & $*$ & $*$ & $\mathrm{~N}$ \\
\hline CPI133872 & & $\mathrm{S}$ & HS & HS & $*$ & MR & MS & $*$ \\
\hline SABUF/7/ALTAR84 & & $\mathrm{S}$ & HS & HS & $*$ & $*$ & $\mathrm{~S}$ & $*$ \\
\hline VP5053 & Cres & $\mathrm{S}$ & HS & HS & HS & $\mathrm{R}$ & HS & $\mathrm{S}$ \\
\hline KRC66/SERI/4/YMH/TOB//MCD/3/LIRA & & $\mathrm{S}$ & HS & HS & HS & $*$ & $*$ & $\mathrm{~N}$ \\
\hline Potch92 & & $\mathrm{S}$ & HS & HS & $\mathrm{S}$ & $*$ & HS & $\mathrm{N}$ \\
\hline $\begin{array}{l}\text { SABUF/3/BCN//CETA/AE.SQUARROSA } \\
(895)\end{array}$ & & $\mathrm{S}$ & HS & HS & S & $*$ & HS & $\mathrm{N}$ \\
\hline ALTAY 2000 & & $\mathrm{~S}$ & HS & HS & $*$ & $*$ & HS & $*$ \\
\hline ID-2150 & $\mathrm{Cre} 2$ & $\mathrm{~S}$ & HS & HS & $\mathrm{S}$ & $\mathrm{S}$ & $*$ & MS \\
\hline GS50A T41.1 & $P t ?$ & $\mathrm{~S}$ & HS & $\mathrm{S}$ & $\mathrm{S}$ & $*$ & $*$ & $*$ \\
\hline AUSGS50AT34/SUNCO//CUNNINGHAM-98 & & $\mathrm{S}$ & HS & HS & $\mathrm{S}$ & $\mathrm{S}$ & $\mathrm{S}$ & $\mathrm{P}$ \\
\hline GATCHER & & $\mathrm{S}$ & HS & HS & $\mathrm{S}$ & $*$ & HS & $\mathrm{N}$ \\
\hline VL411R & & $\mathrm{S}$ & HS & HS & HS & HS & HS & $\mathrm{S}$ \\
\hline $6 \mathrm{R}(6 \mathrm{D})$ & CreR & $\mathrm{S}$ & HS & HS & HS & HS & $\mathrm{R}$ & MR \\
\hline SUNCO/2*PASTOR & & $\mathrm{S}$ & HS & HS & HS & $*$ & HS & $\mathrm{N}$ \\
\hline F130L1.12/ATTILA & & $\mathrm{S}$ & HS & HS & $S$ & $\mathrm{~S}$ & $*$ & $\mathrm{~N}$ \\
\hline BURBOT-6 & & $\mathrm{S}$ & HS & HS & $\mathrm{S}$ & $*$ & $*$ & $\mathrm{~N}$ \\
\hline SONMEZ & & MS & HS & HS & $\mathrm{S}$ & $\mathrm{S}$ & $*$ & $\mathrm{~N}$ \\
\hline AUS4930.7 & Crel? & MS & $\mathrm{S}$ & $\mathrm{S}$ & $\mathrm{S}$ & $*$ & HS & $\mathrm{P}$ \\
\hline T-2003 & Cre7 & MS & $\mathrm{S}$ & $\mathrm{S}$ & MS & $\mathrm{R}$ & HS & MS \\
\hline BATAVIA & & MS & HS & HS & $\mathrm{S}$ & $*$ & HS & $\mathrm{N}$ \\
\hline ZANDER-44 & & MS & $\mathrm{S}$ & $\mathrm{S}$ & $\mathrm{S}$ & $*$ & HS & $\mathrm{N}$ \\
\hline WARIGAL & & MS & HS & HS & HS & $*$ & HS & $\mathrm{N}$ \\
\hline GOLDMARK & & MS & $\mathrm{S}$ & HS & $\mathrm{S}$ & $*$ & HS & $\mathrm{N}$ \\
\hline ES84.24/GRK & & MS & $\mathrm{S}$ & HS & HS & $*$ & HS & $\mathrm{N}$ \\
\hline AUS4930.7/2*PASTOR & Crel? & MS & $\mathrm{S}$ & HS & MR & $\mathrm{R}$ & HS & $\mathrm{N}$ \\
\hline SERI & & MS & HS & HS & $\mathrm{R}$ & $*$ & HS & $\mathrm{N}$ \\
\hline $\begin{array}{l}\text { ALTAR84/AEGILOPSSQUARROSA } \\
\text { (TAUS)//OPATA }\end{array}$ & & MS & HS & HS & MS & & $*$ & $\mathrm{~N}$ \\
\hline Frame & Cres & MS & MS & MR & MS & MR & HS & $\mathrm{P}$ \\
\hline IWA 8604765(PI 628144) & & MR & MS & $\mathrm{S}$ & $*$ & $*$ & $*$ & $*$ \\
\hline IWA 8608077(PI 621458) & & MR & MS & $\mathrm{S}$ & $*$ & $*$ & $*$ & $*$ \\
\hline MILAN & Cre5? & MR & MR & MR & MS & MR & HS & $\mathrm{P}$ \\
\hline KATEA-1 & & MR & MR & MR & MS & HS & HS & $\mathrm{N}$ \\
\hline VP1620 & Cre3 & $\mathrm{R}$ & $\mathrm{R}$ & $\mathrm{R}$ & MR & HS & HS & $\mathrm{S}$ \\
\hline VENTURA(SUN376G) & & $\mathrm{R}$ & MR & MR & $\mathrm{R}$ & $*$ & HS & $\mathrm{N}$ \\
\hline AUS4930 6.5/GS50A & $P t ?$ & $\mathrm{R}$ & HS & HS & $*$ & $*$ & $*$ & $\mathrm{~N}$ \\
\hline $\begin{array}{l}\text { CROC-1/AE.SQUARROSA } \\
\text { (224)//OPATA*A }\end{array}$ & & $\mathrm{R}$ & $\mathrm{R}$ & $\mathrm{R}$ & $\mathrm{R}$ & $\mathrm{R}$ & MR & $\mathrm{S}$ \\
\hline $\begin{array}{l}\text { CROC_1/AE.SQUARROSA } \\
(224) / / \text { OPATA*B }\end{array}$ & & M & M & M & $*$ & $*$ & $*$ & $*$ \\
\hline Wenmai19 & & HS & HS & HS & HS & $*$ & HS & $*$ \\
\hline
\end{tabular}

w* indicates not tested; gene and reaction are the same as in Table 1.

$\mathrm{x}$ The present study was conducted in naturally infested fields in 2012 and in a greenhouse by artificial inoculation in 2013 and 2014 .

y Tested organism was $H$. avenae.

$\mathrm{z}$ Tested organism was $H$. filipjevi; $\mathrm{P}=$ positive for resistance, $\mathrm{N}=$ negative for resistance. 
1993; Ogbonnaya et al. 2001, 2009). In addition, the genes Cre5 and Cre 8 confer partial resistance to pathotype $\mathrm{Ha} 13$, and $\mathrm{Cre} 5$ is partially effective against Ha12 and Ha41 (Jahier et al. 2001; Ogbonnaya et al. 2001). Although $\mathrm{CreR}$ confers resistance or moderate resistance to H. filipjevi (Nicol and Rivoal 2008; Nicol et al. 2009; Yuan et al 2011), cultivars carrying this gene were found to be highly $S$ to the $H$. avenae population used in the present study, similar to findings reported by Smiley et al. (2011), Smiley (2014), and Li et al. (2013)

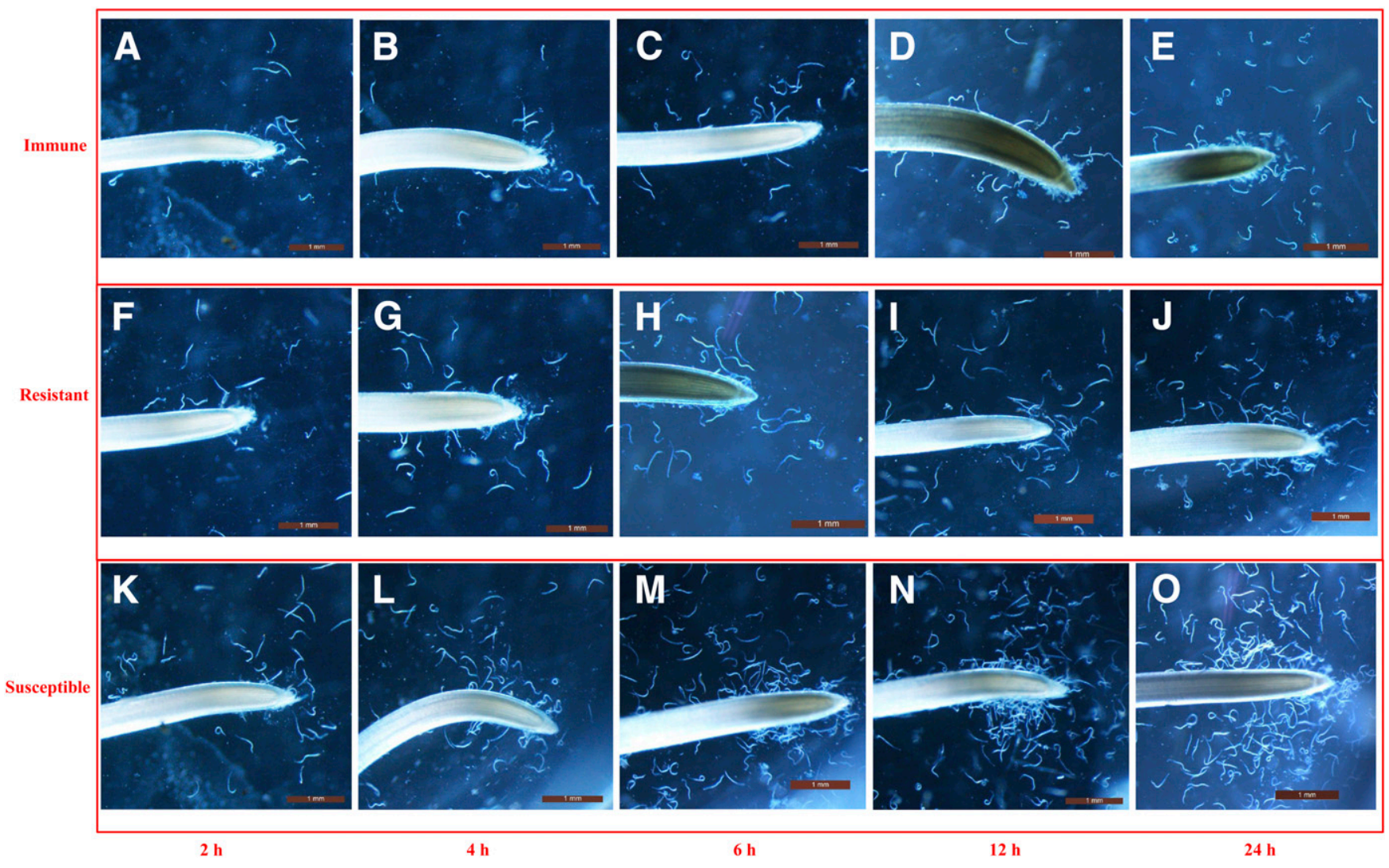

Fig. 1. Attraction of Heterodera avenae (pathotype Ha91) juveniles toward immune, resistant, and susceptible wheat root tips in Pluronic F-127 gel. Scale bar $=1 \mathrm{~mm}$. A-E, Observations at $2 \mathrm{~h}(\mathbf{A}), 4 \mathrm{~h}(\mathbf{B}), 6 \mathrm{~h}(\mathbf{C}), 12 \mathrm{~h}(\mathbf{D})$, and $24 \mathrm{~h}(\mathbf{E})$ after the initiation of interaction between roots and juveniles in the immune wheat root group. F-J, Observations at $2 \mathrm{~h}(\mathbf{F}), 4 \mathrm{~h}(\mathbf{G}), 6 \mathrm{~h}(\mathbf{H})$, $12 \mathrm{~h}(\mathbf{I})$, and $24 \mathrm{~h}(\mathbf{J})$ after the initiation of interaction between roots and juveniles in the resistant wheat root group. K-O, Observations at $2 \mathrm{~h}(\mathbf{K}), 4 \mathrm{~h}(\mathbf{L}), 6 \mathrm{~h}(\mathbf{M}), 12 \mathrm{~h}(\mathbf{N})$, and $24 \mathrm{~h}(\mathbf{O})$ after the initiation of interaction between roots and juveniles in the susceptible wheat root group.

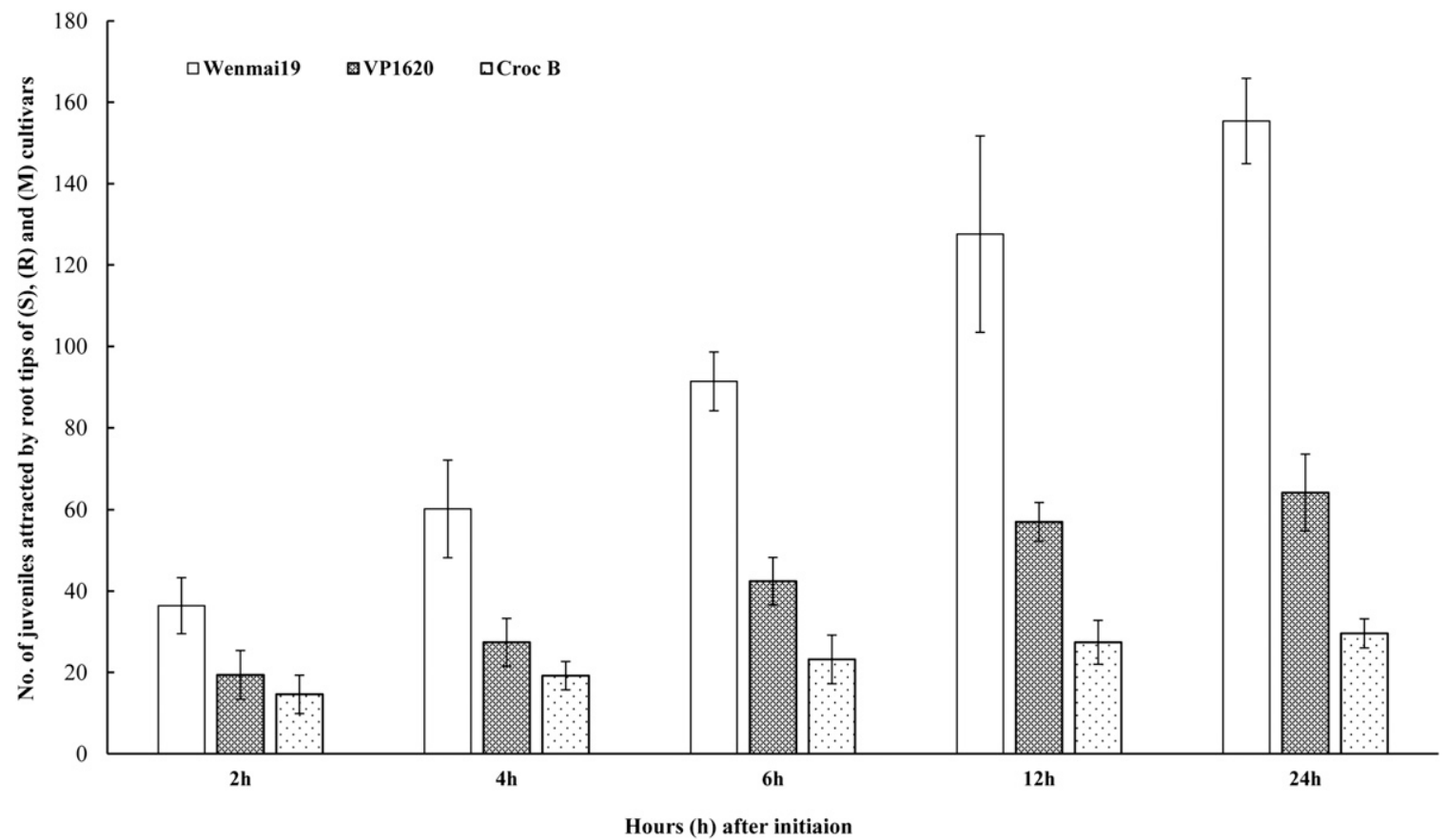

Fig. 2. Differences in the attraction of Heterodera avenae (pathotype Ha91) juveniles in Pluronic F-127 gel toward wheat root tips with different resistance levels. Each point represents the mean of five replicates; the vertical bars indicate the standard deviation of the mean. 
(Table 3). Moreover, Nicol et al. (2011) reported that both $\mathrm{CreR}$ and Crel were effective sources of resistance against $H$. avenae populations from Henan, China, whereas these genes were both compatible with $H$. avenae pathotype Ha91. Similarly, Nicol et al. (2011) observed VL411R to be the most useful cultivar in both Henan and Hebei, which was inconsistent with the results of Li et al. (2013). Varying degrees of resistance to a given plant disease are usually due to differences in the examined environments, populations, and methods, and we suggest that these differences were the reason for the differences observed in the present work.

Host resistance was examined in relation to nematode attraction toward and penetration of roots, as well as to nematode motility, maturation, and reproduction within roots (Linsell et al. 2014). The penetration of $\mathrm{J} 2 \mathrm{~s}$ into $\mathrm{R}$ and $\mathrm{M}$ cultivars was significantly reduced compared with $\mathrm{S}$ cultivars, and the nematodes were unable to develop into mature females, reflecting the resistance reaction of the host. In addition to migration, nematode multiplication was greatly inhibited by plant resistance. Infection assays have shown that $\mathrm{R}$ cultivars could hinder the development of soybean cyst nematodes and significantly reduce the final number of cysts (Liu et al. 2015). Indeed, only 10\% of Pratylenchus thornei juveniles developed to the next stage in $\mathrm{R}$ roots compared with roots from $S$ cultivars (Linsell et al. 2014). In the present study, the mean numbers of $\mathrm{J} 2 \mathrm{~s}, \mathrm{~J} 3 \mathrm{~s}$, and $\mathrm{J} 4 \mathrm{~s}$ observed in the roots of the $\mathrm{S}$ cultivar Wenmai19 were 4.4-, 8.7-, and 14.4-fold higher than in the roots of the R cultivar VP1620 and 8.1-, 45.3-, and 53.3-fold higher than in the roots of the $\mathrm{M}$ cultivar Croc B, respectively. These findings suggest that molting is also suppressed or delayed in $\mathrm{R}$ and $\mathrm{M}$ genotypes. This conclusion is supported by the results of Pariyar et al. (2016), who observed nematode development to be reduced in $\mathrm{R}$ and $\mathrm{MR}$ accessions. During CCN development, juveniles penetrating $\mathrm{S}$ and MR cultivars were able to successfully complete their life cycle, whereas this was not the case for the $\mathrm{M}$ cultivar. The invaded $\mathrm{J} 2 \mathrm{~s}$ gradually declined and failed to develop beyond $\mathrm{J} 3 \mathrm{~s}$; furthermore, $\mathrm{J} 2 \mathrm{~s}$ were still found at 35 and 63 DAI, indicating that reproductive development was suppressed in the M cultivar. The numbers of white female cysts per plant ranged from 0.2 to 4.8 in the roots of the $\mathrm{R}$ cultivars, and the observed decrease in reproduction indicates that the nematodes either exited the $\mathrm{R}$ roots or failed to develop and reproduce.

To achieve a successful parasitic interaction, nematodes must sense and respond precisely to a range of chemical signals (Reynolds et al. 2011). Host tropism is thought to involve root exudates that can stimulate the attraction of nematodes toward host roots either directly or via modification of the rhizosphere (Prot 1980). In our study, juveniles were found surrounding the root tips in Pluronic F-127 gel regardless of whether the wheat cultivar was $\mathrm{M}, \mathrm{R}$, or $\mathrm{S}$. For compatible interactions, a plant must be attractive to specific nematodes (Curtis 2008), and Kaplan et al. (1980) reported suppressed motility in R roots and associated this response with the accumulation of phytoalexins, such as glyceollin. While ethylene is a key molecule in nematode attraction (Kammerhofer et al. 2015), the compounds responsible

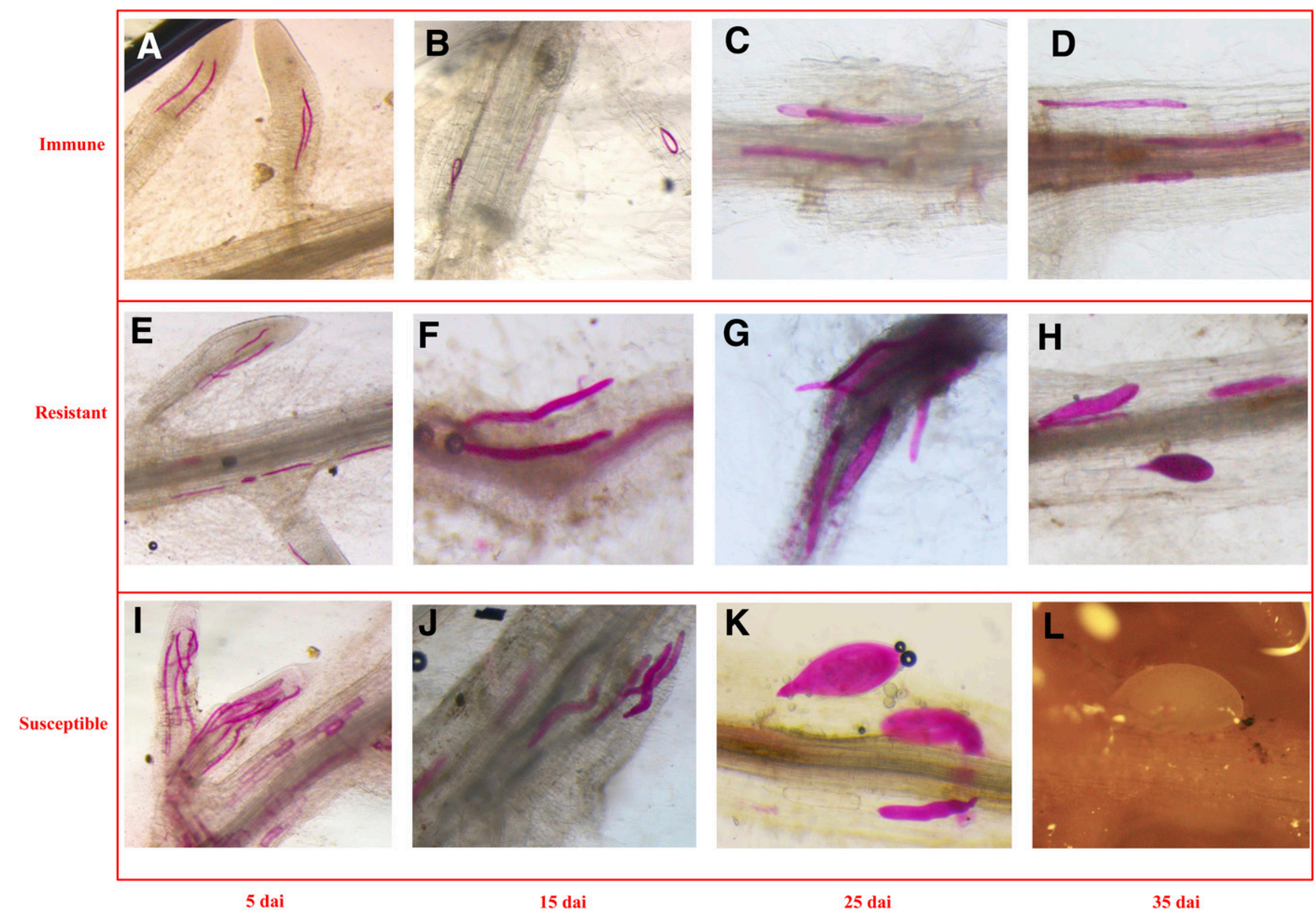

Fig. 3. Penetration and developmental differences of Heterodera avenae (pathotype Ha91) in immune, resistant, and susceptible wheat roots. A-D, Observations of juveniles of different developmental stages in the immune wheat root group at $5 \mathrm{DAl}(\mathrm{A}, \mathrm{J} 2 \mathrm{~s}$ have only penetrated the lateral root elongation region, and no J2s are found in the main roots), 15 DAI (B, J2s and a few developed J3s are present in the root tip), $25 \mathrm{DAI}$ (C, J2s and J3s are present in the root tip), and $35 \mathrm{DAl}$ (D, fewer J2s and J3s are present in the root tip). E-H, Observations of juveniles of different developmental stages in the resistant wheat root group at $5 \mathrm{DAI}(\mathrm{E}$, many $\mathrm{J} 2 \mathrm{~s}$ have penetrated the lateral root elongation region, and few are present in the main roots), $15 \mathrm{DAl}(\mathrm{F}$, many J3s and few J2s are present in the same plant roots), $25 \mathrm{DAl}$ (G, several J4s and J3s and few J2s are present in the same plant roots), and $35 \mathrm{DAl}(\mathrm{H}$, several J4s and few J2s and J3s are present in the same plant roots). I-L, Observations of juveniles of different developmental stages in the susceptible wheat root group at $5 \mathrm{DAl}$ (I, many J2s have penetrated the lateral root elongation region and main roots), $15 \mathrm{DAI}$ (J, J3s and few J2s are present in the same plant roots), $25 \mathrm{DAl}$ (K, several $\mathrm{J} 4 \mathrm{~s}$ and few J3s are present in the same plant roots), and $35 \mathrm{DAl}$ (L, many white females protrude from the roots). 
for the attraction of $H$. avenae to Wenmai19, VP1620, and Croc B have not yet been identified. Andres et al. (2001) reported that infection of $\mathrm{R}$ wheat lines with $H$. avenae resulted in a hypersensitive reaction, with deterioration of syncytial cells. However, the syncytia of the $S$ wheat cultivar grew considerably and were packed with dense cytoplasm, exhibiting wall ingrowths considered to be a specialization for promoting nutrient transport for developing nematodes (Andres et al. 2001; Siddique et al. 2012). The size of the syncytia increased gradually with nematode development in $\mathrm{S}$ cultivars, which is consistent with previous reports (Grundler et al. 1998). One previous study identified $\mathrm{R}$ lines as exhibiting delays and degeneration in syncytial formation in comparison with an S cultivar at several time points (Palomares-Rius et al. 2012). The results regarding the structure of the syncytia in the $\mathrm{M}$ wheat cultivar Croc B indicated late syncytial initiation, increased necrosis, and early syncytial degeneration as signs of a host resistance reaction. Williams and Fisher (1993) reported that syncytia in an S cultivar became highly active at 15 DAI, with an increased volume of cytoplasm with numerous organelles. In contrast, the syncytia of an R cultivar were dominated by coalescing large vacuoles with reduced cytoplasm. The syncytial cytoplasm in the R cultivar had completely disintegrated at 33 DAI, which was consistent with our finding that the syncytia of the $\mathrm{R}$ cultivar degenerated at later $H$. avenae developmental stages.

Because CCNs are host specific, host resistance will continue to be the most profitable and easily applied management strategy (Rivoal and Nicol 2009). Indeed, the identification of $R$ wheat and barley cultivars for production applications in China has become a priority grain project. However, few sources of genetic resistance against $\mathrm{CCNs}$ have been documented in bread wheat (Triticum aestivum). China is a large country with a variable climate, and the species and population pathotypes of CCNs present are quite complex; this situation increases the difficulty of screening $\mathrm{R}$ cultivars for common use. Despite the highly abundant resources for Chinese native wheat varieties, no R cultivars are yet available. Fortunately, an increasing number of nematologists have contributed to resistance screening studies over the years, and significant wheat variety resources in China have been obtained. Our results confirm five wheat cultivars as being $\mathrm{R}$ to $H$. avenae pathotype $\mathrm{Ha} 91$. We are currently studying the mechanism of resistance in these varieties in order to combine genetic breeding with plant allelopathy.

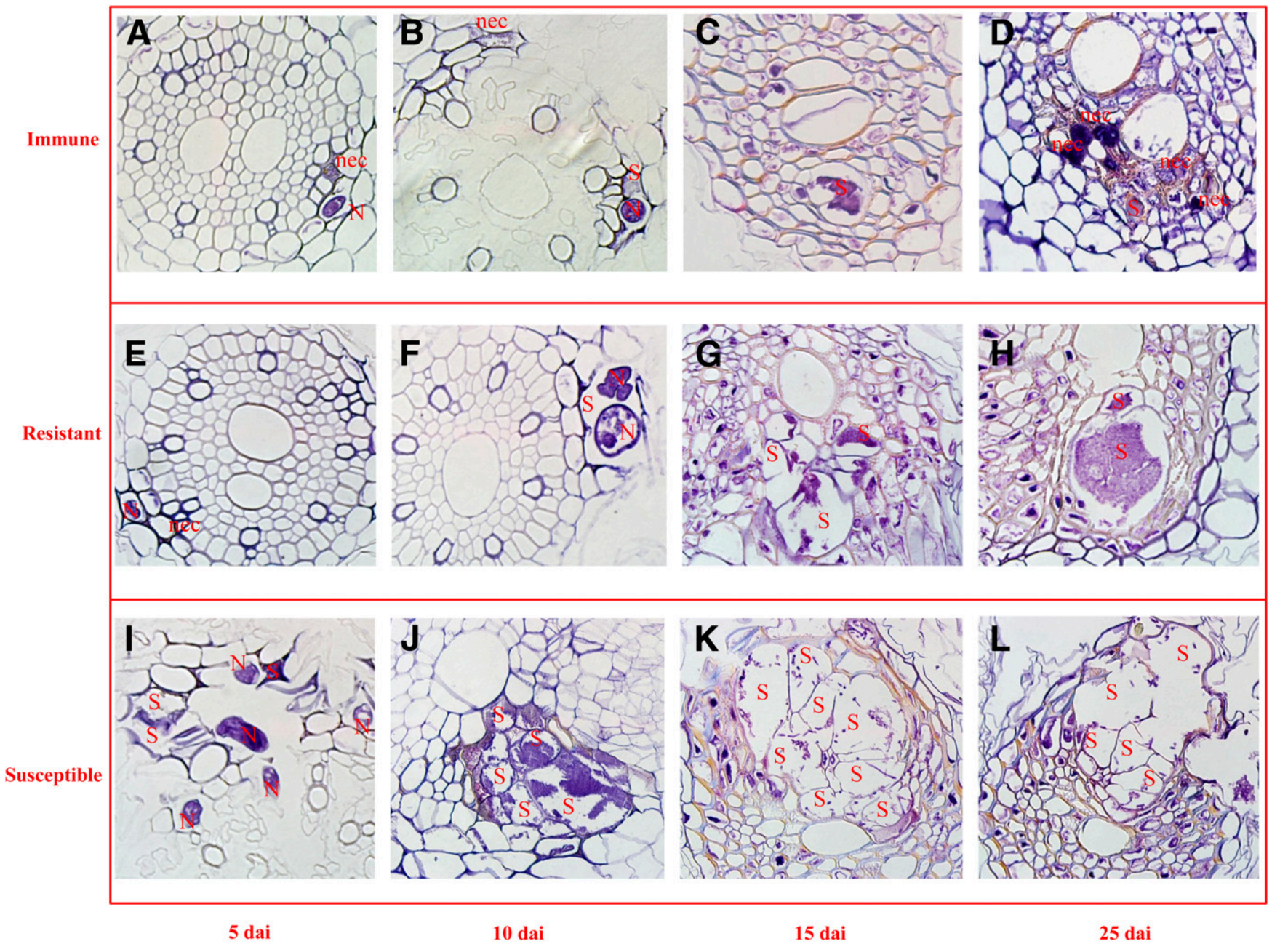

Fig. 4. Syncytial structure showing the development of the syncytium induced by Heterodera avenae (pathotype Ha91) in immune, resistant, and susceptible wheat roots. A-D, Observations in histological sections from the immune wheat root group at $5 \mathrm{DAI}$ (A, showing necrosis near the nematode head and feeding site initiation in endodermal cells), 10 DAl (B, cell fusion), $15 \mathrm{DAl}$ (C, showing syncytia in the roots), and $25 \mathrm{DAl}$ (D, showing syncytial apoptosis) after the initiation of the interaction between roots and juveniles. E-H, Observations in histological sections from the resistant wheat root group at $5 \mathrm{DAl}$ (E, showing feeding site initiation near endodermis cells), $10 \mathrm{DAl}$ (F, showing a large syncytium and hypertrophied nucleus), $15 \mathrm{DAl}$ (G, showing many larger vacuoles and lateral meristems), and $25 \mathrm{DAl}$ (H, showing the syncytium restricted by xylem cells, lateral meristems, and the beginning of syncytium degeneration). I-L, Observations in histological sections from the susceptible group of wheat roots at 5 DAI (I, showing the initiation of the syncytium from central metaxylem cells, necrosis surrounding the nematode head and perforation of the cell walls), $10 \mathrm{DAl}$ ( $\mathrm{J}$, showing a large syncytium stretching from the endodermis to the central xylem), $15 \mathrm{DAl}$ (K, showing a large syncytium containing hypertrophied active nuclei and small vacuoles, phloem cells deformed by the syncytium, and adjacent metaxylem fusion), and $25 \mathrm{DAl}$ (L, showing larger syncytia and syncytium coalescence) after the initiation of interaction between roots and juveniles. Scale bar $=50 \mu \mathrm{m}, \mathrm{N}=$ nematode, $\mathrm{S}=$ syncytia, nec $=$ necrosis. 


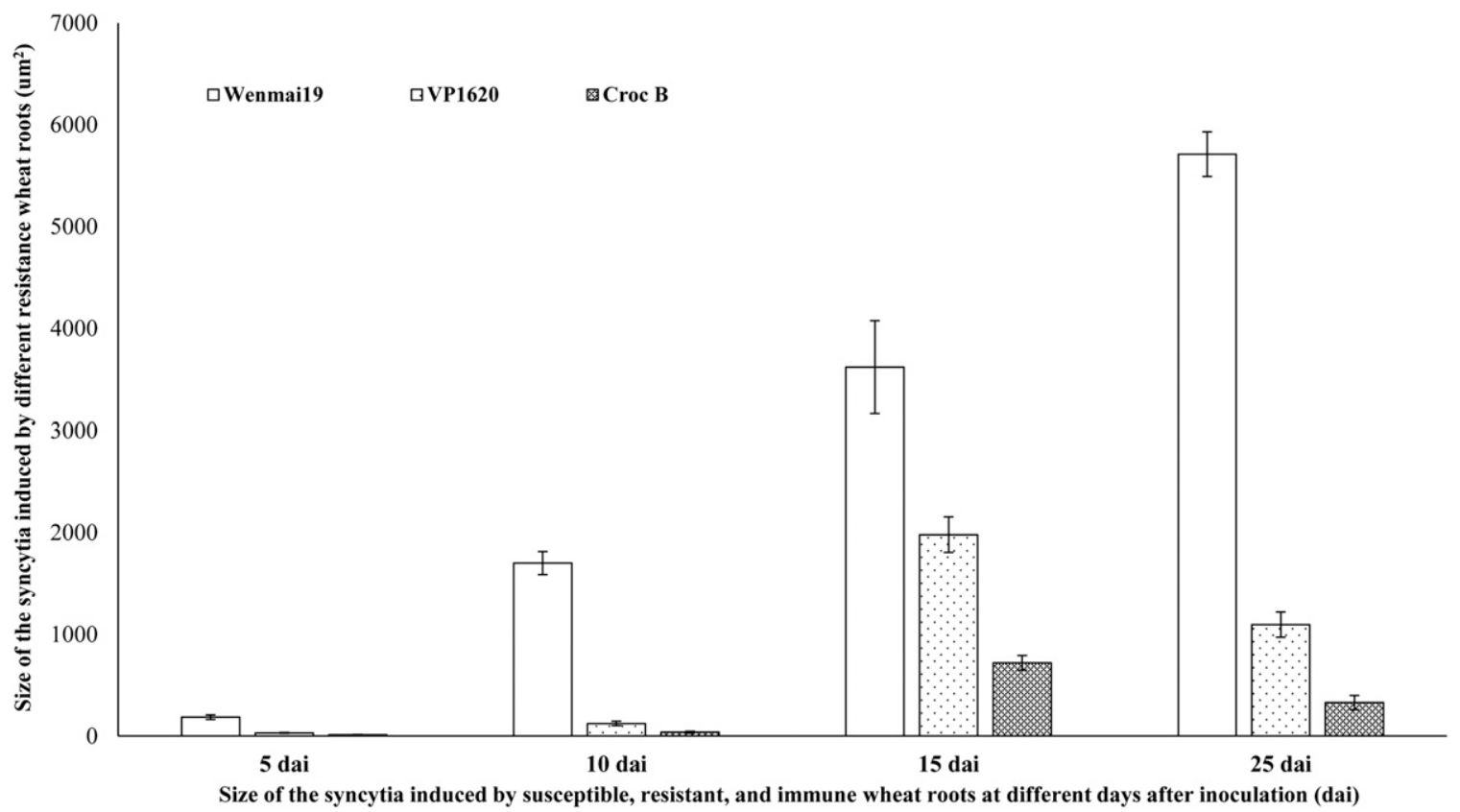

Fig. 5. Sizes of the syncytia induced by immune, resistant, and susceptible wheat roots at different days after inoculation (dai). Each point represents the mean of 10 replicates; vertical bars indicate the standard deviation of the mean.

\section{Acknowledgments}

This study was financially supported by the Special Fund for Agro-scientific Research in the Public Interest (201503114) and the National Key Basic Research Program of China (973 Program, 2013CB127502). The authors would like to thank the International Wheat and Maize Improvement Center (CIMMYT, Mexico) for providing the materials and Prof. Alison Robertson and Prof. Mark Gleason (Iowa State University, U.S.A.) for critical reading of the manuscript. We are truly grateful to Prof. Richard W. Smiley (Oregon State University, U.S.A.) for providing scientific advice and for revising the manuscript.

\section{Literature Cited}

Aditya, J., Lewis, J., Shirley, N. J., Tan, H. T., Henderson, M., Fincher, G. B., Burton, R. A., Mather, D. E., and Tucker, M. R. 2015. The dynamics of cereal cyst nematode infection differ between susceptible and resistant barley cultivars and lead to changes in $(1,3 ; 1,4)$-beta-glucan levels and $\mathrm{HvCslF}$ gene transcript abundance. New Phytol. 207:135-147.

Andres, M. F., Melillo, M. T., Delibes, A., Romero, M. D., and Bleve-Zacheo, T. 2001. Changes in wheat root enzymes correlated with resistance to cereal cyst nematodes. New Phytol. 152:343-354.

Barloy, D., Lemoine, J., Abelard, P., Tanguy, A. M., Rivoal, R., and Jahier, J. 2007. Marker-assisted pyramiding of two cereal cyst nematode resistance genes from Aegilops variabilis in wheat. Mol. Breed. 20:31-40.

Barr, A. R., Chalmers, K. J., Karakousis, A., Kretschmer, J. M., Manning, S., Lance, R. C. M., and Langridge, P. 1998. RFLP mapping of a new cereal cyst nematode resistance locus in barley. Plant Breed. 117:185-187.

Bybd, D. W., Kirkpatrick, T., and Barker, K. R. 1983. An improved technique for clearing and staining plant tissues for detection of nematodes. J. Nematol. 15:142-143.

Clamot, G., and Rivoal, R. 1984. Genetic resistance to cereal cyst nematode Heterodera avenae Woll. in wild oat Avena sterilis I. 376. Euphytica 33:27-32.

Cui, J., Huang, W., Peng, H., Liu, S., Wang, G., Kong, L., and Peng, D. 2015. A new pathotype characterization of Daxing and Huangyuan populations of cereal cyst nematode (Heterodera avenae) in China. J. Integr. Agric. 14:724-731.

Cui, J. K., Huang, W., Peng, H., Lv, Y., Kong, L., Li, H., Luo, S., Wang, Y., and Peng, D. L. 2017. Efficacy evaluation of seed-coating compounds against cereal cyst nematodes and root lesion nematodes on wheat. Plant Dis. 101:428-433.

Cui, L., Gao, X., Wang, X. M., Jian, H., Tang, W. H., Li, H. L., and Li, H. J. 2012. Characterization of interaction between wheat roots with different resistance and Heterodera filipjevi. Acta Agron. Sin. 38:1009-1017.

Curtis, R. H. 2008. Plant-nematode interactions: Environmental signals detected by the nematode's chemosensory organs control changes in the surface cuticle and behaviour. Parasite 15:310-316.

Delibes, A., Romero, D., Aguaded, S., Duce, A., Mena, M., Lopez-Braña, I., Andrés, M. F., Martin-Sanchez, J. A., and García-Olmedo, F. 1993. Resistance to the cereal cyst nematode (Heterodera avenae Woll.) transferred from the wild grass Aegilops ventricosa to hexaploid wheat by a "stepping-stone" procedure. Theor. Appl. Genet. 87:402-408.

de Majnik, J., Ogbonnaya, F. C., Moullet, O., and Lagudah, E. S. 2003. The Cre1 and $\mathrm{Cre} 3$ nematode resistance genes are located at homeologous loci in the wheat genome. Mol. Plant-Microbe Interact. 16:1129-1134.
Eastwood, R. F., Lagudah, E. S., Appels, R., Hannah, M., and Kollmorgen, J. F. 1991. Triticum tauschii: A novel source of resistance to cereal cyst nematode (Heterodera avenae). Crop Pasture Sci. 42:69-77.

Grundler, F. M. W., Sobczak, M., and Golinowski, W. 1998. Formation of wall openings in root cells of Arabidopsis thaliana following infection by the plantparasitic nematode Heterodera schachtii. Eur. J. Plant Pathol. 104:545-551.

Hao, R., Huang, W. K., Liu, C., Peng, D. L., Li, H. M., and Li, H. X. 2014. Effect of seed-coatings on controlling cereal cyst nematode (Heterodera avenae) of wheat. Plant Prot. 40:182-186.

Hou, S. Y., Wang, A. L., Zhang, G., and Huang, L. L. 2012. Effect of cereal cyst nematode on agronomic characteristics and yield losses of spring wheat. J. Agric. 2:31-36.

Hu, X. B., Liang, X., Zhang, L., Chen, Y., Wang, X., and Li, H. M. 2015. Phenotype characterization of interaction between different wheat cultivars and Heterodera avenae. Plant Prot. 41:78-83.

Jahier, J., Abelard, P., Tanguy, M., Dedryver, F., Rivoal, R., Khatkar, S., Bariana, H. S., and Koebner, R. 2001. The Aegilops ventricosa segment on chromosome 2AS of the wheat cultivar 'VPM1' carries the cereal cyst nematode resistance gene Cre5. Plant Breed. 120:125-128.

Jahier, J., Rivoal, R., Yu, M. Q., Abelard, P., Tanguy, A. M., and Barloy, D. 1998. Transfer of genes for resistance to cereal cyst nematode from Aegilops variabilis Eig to wheat. J. Genet. Breed. 52:253-257.

Kammerhofer, N., Radakovic, Z., Regis, J. M., Dobrev, P., Vankova, R., Grundler, F. M., Siddique, S., Hofmann, J., and Wieczorek, K. 2015. Role of stress-related hormones in plant defence during early infection of the cyst nematode Heterodera schachtii in Arabidopsis. New Phytol. 207:778-789.

Kaplan, D. T., Keen, N. T., and Thomason, I. J. 1980. Association of glyceollin with the incompatible response of soybean roots to Meloidogyne incognita. Physiol. Plant Pathol. 16:309-318.

Kong, L. A., Wu, D. Q., Cui, J. K., Huang, W. K., Peng, H., and Peng, D. L. 2016 Testing and modelling the potential of three diploid plants in poaceae as a new pathosystem to investigate the interactions between cereal hosts and cereal cyst nematode (Heterodera avenae). Plant Pathol. 65:682-688.

Li, X. H., Juan, M. A., Gao, B., Wang, R. Y., and Chen, S. L. 2013. Resistance of wheat cultivars or germplasm lines to Heterodera avenae. J. Triticeae Crops. 33:1277-1283

Lilley, C. J., Atkinson, H. J., and Urwin, P. E. 2005. Molecular aspects of cyst nematodes. Mol. Plant Pathol. 6:577-588.

Linsell, K. J., Riley, I. T., Davies, K. A., and Oldach, K. H. 2014. Characterization of resistance to Pratylenchus thornei (Nematoda) in wheat (Triticum aestivum): Attraction, penetration, motility, and reproduction. Phytopathology 104:174-187.

Liu, S. S., Yang, Q., and Jian, H. 2015. Resistance evaluation of soybean germplasms to soybean cyst nematodes. Acta Phytopathol. Sin. 45:317-325.

Marshall, J. M., and Smiley, R. W. 2016. Spring barley resistance and tolerance to the cereal cyst nematode Heterodera avenae. Plant Dis. 100:396-407.

Miller, T. D. 1992. Growth stages of wheat: identification and understanding improve crop management. Better Crops, Summer:12-17.

Mitchum, M. G., Hussey, R. S., Baum, T. J., Wang, X., Elling, A. A., Wubben, M., and Davis, E. L. 2013. Nematode effector proteins: An emerging paradigm of parasitism. New Phytol. 199:879-894. 
Nicol, J., Ogbonnaya, F., Singh, A., Bishnoi, S., Kanwar, R., Li, H. L., Chen, S. L., Peng, D. L., Bolat, N., and Şahin, E. 2009. Current global knowledge of the usability of cereal cyst nematode resistant bread wheat germplasm through international germplasm exchange and evaluation. Pages 149-153 in: Cereal Cyst Nematodes: Status, Research and Outlook. I. T. Riley, J. M. Nicol, and A. Dababat, eds. International Maize and Wheat Improvement Centre (CIMMYT), Ankara, Turkey.

Nicol, J. M., and Rivoal, R. 2008. Global knowledge and its application for the integrated control and management of nematodes on wheat. Pages 251-294 in: Integrated Management and Biocontrol of Vegetable and Grain Crops Nematodes. A. Ciancio and K. Mukerji, eds. Springer, Dordrecht, The Netherlands.

Nicol, J. M., Turner, S. J., Coyne, D., Den Nijs, L., Hockland, S., and Maafi, Z. T. 2011. Current nematode threats to world agriculture. Pages 21-43 in: Genomics and Molecular Genetics of Plant-Nematode Interactions. J. Jones, et al., eds. Springer, Dordrecht, The Netherlands.

Ogbonnaya, F. C., Eastwood, R., and Lagudah, E. 2009. Identification and utilisation of genes for cereal cyst nematode resistance (Heterodera avenae) resistance in wheat: The Australian experience. Pages 166-171 in: Cereal Cyst Nematodes: Status, Research and Outlook. I. T. Riley, J. M. Nicol, and A. Dababat, eds. International Maize and Wheat Improvement Centre (CIMMYT), Ankara, Turkey.

Ogbonnaya, F. C., Seah, S., Delibes, A., Jahier, J., López-Braña, I., Eastwood, R. F., and Lagudah, E. S. 2001. Molecular-genetic characterisation of a new nematode resistance gene in wheat. Theor. Appl. Genet. 102:623-629.

Palomares-Rius, J. E., Hedley, P. E., Cock, P. J., Morris, J. A., Jones, J. T., Vovlas, N., and Blok, V. 2012. Comparison of transcript profiles in different life stages of the nematode Globodera pallida under different host potato genotypes. Mol. Plant Pathol. 13:1120-1134.

Pariyar, S. R., Dababat, A. A., Siddique, S., Erginbas-Orakci, G., Elashry, A., Morgounov, A., and Grundler, F. M. 2016. Identification and characterisation of resistance to the cereal cyst nematode Heterodera filipjevi in winter wheat. Nematology 18:377-402.

Peng, D. L., and Cook, R. 1996. Observation on pathotypes of cereal cyst nematode (Heterodera avenae) in China. Int J Nematol. 6:176-178.

Peng, D. L., Nicol, J. M., Li, H. M., Hou, S. Y., Li, H. X., Chen, S. L., Ma, P., Li, H. L., and Riley, I. T. 2009. Current knowledge of cereal cyst nematode (Heterodera avenae) on wheat in China. Pages 29-34 in: Cereal Cyst Nematodes: Status, Research and Outlook. I. T. Riley, J. M. Nicol, and A. Dababat, eds. International Maize and Wheat Improvement Centre (CIMMYT), Ankara, Turkey.

Peng, D. L., Zhang, D., Nicol, J. M., Chen, S. L., Waeyenberge, L., Moens, M., Li, H. L., Tang, W. H., and Riley, I. T. 2007. Occurrence, distribution and integrated management of the cereal cyst nematodes (Heterodera avenae \& H. filipjevi) in China. Pages 350-351 in: Proceedings Proc. XVI Int. Plant Protect Cong., Glasgow, Scotland, U.K. British Crop Protection Council, Alton, Hampshire, U.K.

Persmark, L., Banck, A., Andersson, S., and Jansson, H.-B. 1992. Evaluation of methods for extraction of nematodes and endoparasitic fungi from soil. Nematologica 38:520-530.

Prot, J. C. 1980. Migration of plant-parasitic nematodes towards plant roots. Rev. Nematol. 3:305-318.

Reynolds, A. M., Dutta, T. K., Curtis, R. H., Powers, S. J., Gaur, H. S., and Kerry, B. R. 2011. Chemotaxis can take plant-parasitic nematodes to the source of a chemo-attractant via the shortest possible routes. J. R. Soc. Interface 8:568-577.
Rivoal, R., Bekal, S., Valette, S., Gauthier, J. P., Fradj, M. B. H., Mokabli, A., and Yahyaoui, A. 2001. Variation in reproductive capacity and virulence on different genotypes and resistance genes of Triticeae, in the cereal cyst nematode species complex. Nematology 3:581-592.

Rivoal, R., and Nicol, J. 2009. Past research on the cereal cyst nematode complex and future needs. Pages 3-10 in: Cereal Cyst Nematodes: Status, Research and Outlook. I. T. Riley, J. M. Nicol, and A. Dababat, eds. International Maize and Wheat Improvement Centre (CIMMYT), Ankara, Turkey.

Romero, M. D., Montes, M. J., Sin, E., Lopez-Brana, I., Duce, A., Martin-Sanchez, J. A., and Delibes, A. 1998. A cereal cyst nematode (Heterodera avenae Woll.) resistance gene transferred from Aegilops triuncialis to hexaploid wheat. Theor Appl. Genet. 96:1135-1140.

Safari, E., Gororo, N. N., Eastwood, R. F., Lewis, J., Eagles, H. A., and Ogbonnaya, F. C. 2005. Impact of Cre1, Cre8 and Cre3 genes on cereal cyst nematode resistance in wheat. Theor. Appl. Genet. 110:567-572.

Sasaki-Crawley, A., Curtis, R., Birkett, M., Papadopoulos, A., Blackshaw, R., and Pickett, J. 2012. The use of Pluronic F-127 to study the development of the potato cyst nematode, Globodera pallida. Nematology 14:869-873.

Seah, S., Miller, C., Sivasithamparam, K., and Lagudah, E. S. 2000. Root responses to cereal cyst nematode (Heterodera avenae) in hosts with different resistance genes. New Phytol. 146:527-533.

Siddique, S., Sobczak, M., Tenhaken, R., Grundler, F. M., and Bohlmann, H 2012. Cell wall ingrowths in nematode induced syncytia require ugd 2 and ugd3. PLoS One 7:e41515.

Smiley, R. 2014. Resistance of wheat to a Pacific Northwest population of Heterodera avenae, 2013. Plant Disease Management Reports 8:CF039. American Phytopathological Society, St. Paul, MN.

Smiley, R. W., Yan, G. P., and Pinkerton, J. N. 2011. Resistance of wheat, barley and oat to Heterodera avenae in the Pacific Northwest, USA. Nematology 13 539-552.

Taylor, C., Shepherd, K. W., and Langridge, P. 1998. A molecular genetic map of the long arm of chromosome $6 \mathrm{R}$ of rye incorporating the cereal cyst nematode resistance gene. CreR. Theor. Appl. Genet. 97:1000-1012.

Thompson, J. P., Brennan, P. S., Clewett, T. G., Sheedy, J. G., and Seymour, N. P. 1999. Progress in breeding wheat for tolerance and resistance to root-lesion nematode (Pratylenchus thornei). Australas. Plant Pathol. 28:45-52.

Wang, C., Lower, S., and Williamson, V. M. 2009. Application of Pluronic gel to the study of root-knot nematode behaviour. Nematology 11:453-464.

Williams, K. J., and Fisher, J. M. 1993. Development of Heterodera avenae Woll and host cellular responses in susceptible and resistant wheat. Fund. Appl. Nematol. 16:417-423.

Yuan, H. X., Sun, J. W., Yang, W. X., Xing, X. P., Wang, Z. Y., Riley, I. T., and Li, H. L. 2010. New pathotypes of Heterodera avenae (cereal cyst nematode) from winter wheat in Zhengzhou, Henan, China. Australas. Plant Pathol. 39:107-111.

Yuan, H. X., Zhang, F. X., Zhang, J. J., Hou, X. S., Li, H. J., and Li, H. L. 2011. Resistance of CIMMYT wheat germplasm to Heterodera filipjevi Xuchang population from Henan Province, China. Acta Agron. Sin. 37: 1956-1966.

Zwart, R. S., Thompson, J. P., and Godwin, I. D. 2004. Genetic analysis of resistance to root lesion nematode (Pratylenchus thornei) in wheat. Plant Breed. 123:209-212. 